J. Clin. Chem. Clin. Biodiem.

Vol. 19. 1981, pp. 259-264

\title{
Xanthurenic Acid Excretion in Urine After Oral Intake of 5 Grams $L$-Tryptophan by Healthy Volunteers: Standardisation of the Reference Values
}

By M. J. A. J. M. Hoes

Department of Psychiatry, Bethesda Hospital, Tiel; Department of Psychiatry, Radboud Hospital, Nijmegen.

\section{E. K. J. Kreutzer}

Department of Clinical Chemistry, Bethesda Hospital, Tiel and

\section{N. Sijben}

\section{Department of Psychiatry, Radboud Hospital, Nijmegen}

(Received July 14/November 17,1980 )

\begin{abstract}
Summary: The excretion of xanthurenic acid in urine after oral intake of 5 grams of $L$-tryptophan was studied and correlated with test and test-person parameters. The xanthurenic acid was determined by a colorimetric method, which gives reliable and reproducible results. Two groups, of 11 heal thy volunteers each, participated. The first group started the test at 08.00 hours and the second group at 22.00 hours. Both groups repeated the same test, within one week of the first test, at 22.00 hours. The xanthurenic acid excretion in the 24-hour urine correlated significan tly $(p=0.04)$ with urine volume, but did not correlate with age, sex, height, body-weight, urine pH and urinary output of creatinine or 17-hydroxysteroids. The intraindividual variability of the test is not significant. The test should be started in the evening and the urine should be collected over 24 hours. The new reference values for the xar thurenic acid excretion under these conditions are $68.8 \pm 19.0 \mu \mathrm{mol} / 24 \mathrm{~h}$.
\end{abstract}

\section{Die Ausscheidung von Xanthurensäure im Urin nach oraler Einnahme von $5 \mathrm{~g}$ L-Tryptophan bei gesunden Probanden: Standardisierung der Referenzwerte}

Zusammenfassung: Die Ausscheidung von Xanthurensäure im Urin nach oraler Einnahme von $5 \mathrm{~g}$ L-Tryptophan wurde untersucht und mit Parametern von Test und Test-Personen korreliert. Xanthurensäure wurde nach ciner kolorimetrischen Methode bestimmt, die zuverlässige und reproduzierbare Resul tate ergibt. An der Untersuchung nahmen zwei Gruppen mit je 11 gesunden Probanden teil. Die erste Gruppe begann mit dem Test um 08.00 Uhr morgens, die zweite um 22.00 Uhr abends. Beide Gruppen wiederholten den Test innerhalb einer Woche nach dem ersten, wobei der zweite Test bei beiden Gruppen um 22.00 Uhr begann. Die Xan thurensäurc-Ausscheidung im Urin korrelierte signifikant $(p=0,04)$ mit dem Urinvolumen, zeigte aber keine Korrelation weder mit Alter, Geschlecht, Größe und Gewicht der Probanden, noch mit dem pH-Wert des Urins und der Ausscheidung von Kreatinin oder 17-Hydroxysteroiden im Urin. Die intraindividuellen Schwankungen im Test sind nicht signifikant. Der Test sollte am Abend beginnen und der Urin während 24 Stunden gesammelt werden. Als neue Referenzwerte für die Xanthurensäurc-Ausscheidung im Urin unter diesen Bedingungen gelten $68,8 \pm 19,0 \mu \mathrm{mol} / 24 \mathrm{~h}$.

\section{Introduction}

Xanthurenic acid is a side product from the conversion pathway of $L$-tryptophan into nicotinamide (fig. 1$)$. Disorders of this biosynthesis can be quantified by measuring the excretion of xanthurenic acid in urine after oral intake of a loading dose of $L$-tryptophan. An elevated excretion of xanthurenic acid can be found in vitamin $B_{6}$ deficiency (1), stress (2), the use of oral contraceptives with (3) or without (4) depression, mental retardation $(5,6)$, depression $(7,8)$, hyperventilation syndrome (9) and anxiety state (7). At a biochemical level, 


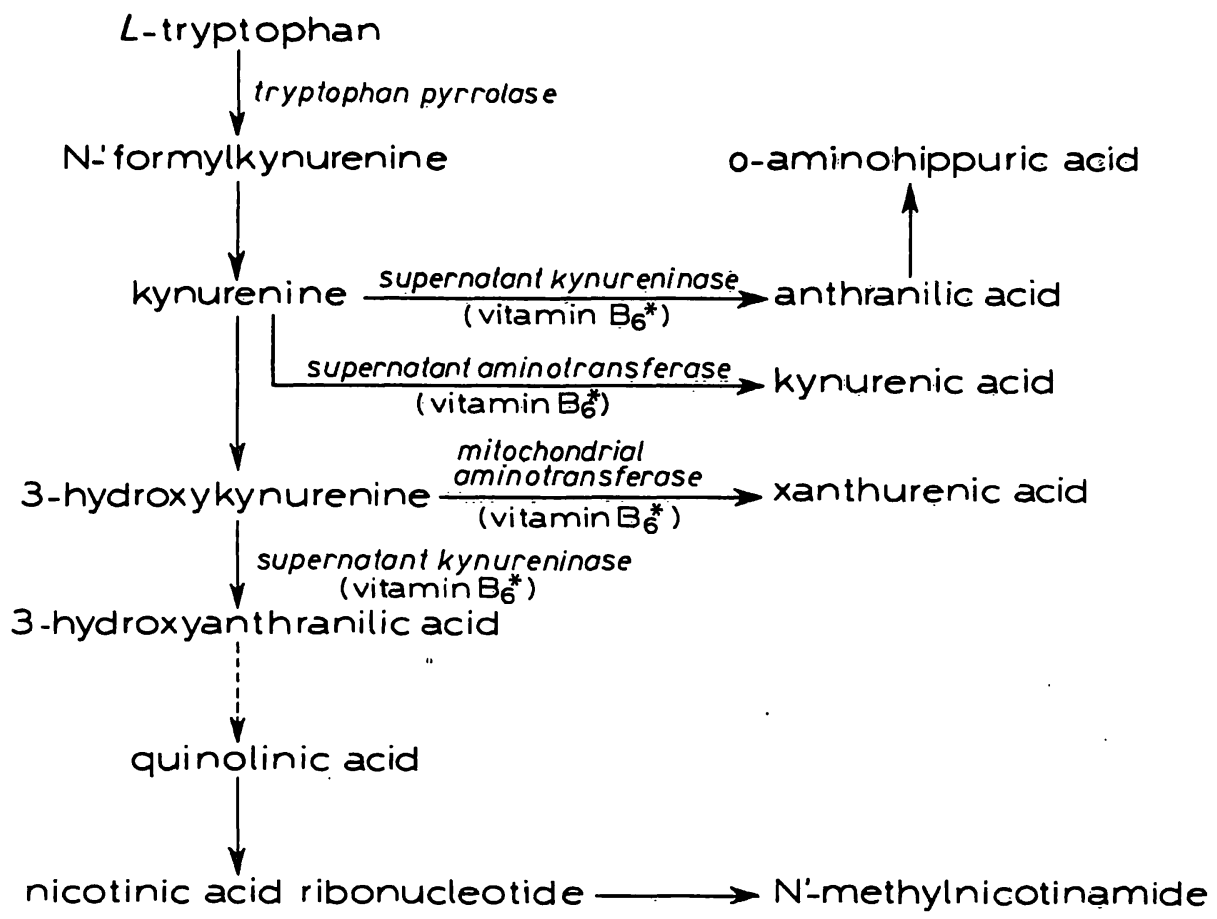

Fig. 1. $L$-tryptophan-nicotinic acid ribonucleotide conversion.

Schematic representation of nicotinic acid biosynthesis. The tryptophan pyrrolase can be induced by steroid hormones.

The enzymes known to require the coenzymatically active form of vitamin $B_{6}$ (vitamin $B_{6}^{*}$ ) are shown.

The mitochondrial aminotransferase is the less sensitive and the supernatant kynureninase the most sensitive enzyme to a deficiency or competetive inhibition of vitamin $B_{6}^{*}$.

Therefore, in persons with a vitamin $\mathrm{B}_{6}^{*}$ deficiency the intake of a loading dose of $L$-tryptophan will be followed by an abnormal formation and excretion of xanthurenic acid, while also kynurenic acid will be formed. However, in a very severe deficiency of vitamin $B_{6}^{*}$, even the excretion of xanthurenic acid will fall below control values.

the elevation of the xanthurenic acid excretion is caused notably by induction of the pyrrolase and competitive inhibition of those enzymes in the nicotinamide synthesis that contain the coenzymatically active form of vitamin $\mathrm{B}_{6}$ (vitamin $\mathrm{B}_{6}^{*}$ ); steroid hormones are important in these mechanisms $(2,4,5)$.

Comparison of these studies, however, shows several problems.

1) There is no standard method for the determination of xanthurenic acid; some workers use colorimetry $(1,7$, $10)$, others an array of chromatographic methods $(3,11)$ or spectrofluorimetry (6).

2) Some authors have administered $L$-tryptophan in a $\mathrm{mg} / \mathrm{kg}$ body-weight dose $(5,6,11)$ and others in a fixed dose $(3,4,7,8,9)$. Even within each of these administration modes the dose used by different authors was not identical.

3) Some authors considered the urine collected during 6 hours after $L$-tryptophan intake (12), others during 8 hours (4), 12 hours (6) or 24 hours $(7,8,9,11)$.

4) The $L$-tryptophan was administered either in the morning $(3,4,6)$ or in the evening $(7,8,9)$. In animal experiments it was shown, however, that there is a considerable circadian variability in the activity of the pyrrolase (13). Variations in the activity of the pyrrolase may cause considerable differences in the amount of $L$-tryptophan metabolized in the nicotinamide synthesis (2).

5) The authors do not mention the extent of intraindividual variability, or the dependence of the xanthurenic acid excretion on test and test-person parameters. In a previous study of the xanthurenic acid excretion in psychiatric patients (7), no correlation was found between the xanthurenic acid excretion and age, sex, urine volume or creatinine excretion.

Because of the problems stated above, there is a need for proper standardisation of the reference values of the xanthurenic acid excretion after loading with $L$-tryptophan.

In previous studies $(7,8,9)$ the subjects were given a loading dose of 5 grams $L$-tryptophan at 22.00 hours and collected their urine during the subsequent 24 hours in a dark bottle; the xanthurenic acid content was measured by colorimetry and expressed as $\mu \mathrm{mol} / 24 \mathrm{~h}$. A further problem in these studies, apart from the above, was that the only available reference values had been obtained from 648 neurologic and psychiatric patients, selected at random. These people were not healthy by definition, although most of them may not have suffered any condition that disturbs the xanthurenic 
acid excretion. The distribution of these 648 values was positively skewed, with a modus of $50 \mu \mathrm{mol} / 24 \mathrm{~h}$, range $0-2,188 \mu \mathrm{mol} / 24 \mathrm{~h}$.

In the present study, the reference values of the xanthurenic acid excretion in the stated procedure are better defined. The effect of starting time of test, the intraindividual variability, the sequential excretion of $x$ anthurenic acid, and the relation of the xanthurenic acid excretion to age, sex, height, body-weight, urine volume, urine $\mathrm{pH}$ and creatinine excretion were studied in heal thy volunteers.

\section{Materials and Methods}

\section{Patient groups}

The volunteers were included only if they had not suffered from any medical or surgical disorder during the last year, nor from a minor disorder, such as common cold, during the last 2 weeks before the test. They were excluded if they were suffering at the moment of the test from alcoholism, depression or anxiety, or if they took any medication or oral contraceptives.

The anxiety and depression were checked by the Hamilton depression (14), Zung depression (15) and Zung anxiety (16) scales.

The participants took 5 grams $L$-tryptophan and collected their urine for the next 24 hours. They were, however, divided into 2 groups. The first group (A) started the test at 08.00 hours; they were fasting and remained so for the next 2 hours. The second group (B) started the test at 22.00 hours. Both groups repeated the same test within one week of the first test at 22.00 hours. For all tests starting at 22.00 hours, the subjects took their last meal at 18.00 hours and collected their urine in 2 portions; one from 22.00 to 08.00 hours and the second from 08.00 to 22.00 hours.

\section{Chemical assays}

Xanthurenic acid was measured with a slightly modified colorimetric method according to Wachstein \& Gudaitis (1) and Weller \& Fichtenbaum (10). The modification consisted of the use of a buffer with an increased (doubled) molarity, that allowed us to omit a neutralization step. The final absorbance is $\mathrm{pH}$-dependent. The absorbance curve is linear between $80-400 \mu \mathrm{mol} / \mathrm{l}$ xanthurenic acid. Below $80 \mu \mathrm{mol} / \mathrm{l}$ the curve bends to the zero point.

\section{Reagents}

1. Buffer $\mathrm{pH}$ 7.6: dissolve $242 \mathrm{~g}$ tris(hydroxymethyl)-methylamine (Merck 8382) and $116 \mathrm{~g} \mathrm{malic}$ acid (Merck 800380) in about $600 \mathrm{ml}$ distilled water. Adjust to $\mathrm{pH} 7.6$ with sodium hydroxide solution. Transfer to a 11 volumetric flask and fill with distilled water to the mark. Store at $4{ }^{\circ} \mathrm{C}$.

2. Ammonium hydroxide solution $25 \%$ (Merck 5432 ).

3. Calcium chloride solution: dissolve in a $100 \mathrm{ml}$ volumetric flask $66.2 \mathrm{~g}$ calcium chloride (Merck 2382) in distilled water and fill up to the mark.

4. Ferric-ammonium sulfate solution: dissolve in a $100 \mathrm{ml}$ volumetric flask $1.7 \mathrm{~g}$ ferric-ammonium sulfate (Merck 3776 ) in a mix ture of $60 \mathrm{ml}$ distilled water and 3 drops $250 \mathrm{~g} / \mathrm{kg}$ hydrochloric acid and fill up to the mark with distilled water.

5. Xanthurenic acid standard solutions:

a. Standard stock solution: dissolve in a $200 \mathrm{ml}$ volumetric flask: $32.8 \mathrm{mg}$ xan thurenic acid (Merck 820480) in $5 \mathrm{ml}$ distilled water and 3 drops $250 \mathrm{~g} / \mathrm{kg}$ ammonium hydroxide solution. Fill up to the mark with distilled water. Store in a brown bottle at $4^{\circ} \mathrm{C}$.

\section{b. Working standard-solutions}

$80 \mu \mathrm{mol} / \mathrm{l}:$ dilute $1.0 \mathrm{ml}$ stock solution with $9.0 \mathrm{ml}$ distilled water.

$200 \mu \mathrm{mol} / \mathrm{l}$ : dilute $2.5 \mathrm{ml}$ stock solution with $7.5 \mathrm{ml}$ distilled water.

$400 \mu \mathrm{mol} / \mathrm{l}$ : dilute $5.0 \mathrm{ml}$ stock solution with $5.0 \mathrm{ml}$ distilled water.

\section{Determination}

Urine is collected during a 24 hours period. All portions are put in a dark bottle, stored at $4^{\circ} \mathrm{C}$. After the collection period the contents of the bottle are mixed, the total volume is recorded and a $100 \mathrm{ml}$ sample is kept at $-20^{\circ} \mathrm{C}$ prior to the determination.

Pipette in centrifuge tubes: $10 \mathrm{ml}$ urine (sample), $10 \mathrm{ml}$ distilled water (reagent blank) and $10 \mathrm{ml}$ standard (standard curve). Add to sample and blank $0.25 \mathrm{ml}$ ammonium hydroxide and $0.25 \mathrm{ml}$ calcium chloride solution.

Add to standard $0.1 \mathrm{ml}$ ammonium hydroxide and $0.4 \mathrm{ml}$ distilled water.

Mix the contents of the tubes after every addition. Centrifuge $10 \mathrm{~min} 3000 \mathrm{rpm}$.

Pipette $6 \mathrm{ml}$ of the clear supernatant in a clear "blank" tube, add $4 \mathrm{ml}$ buffer, $\mathrm{mix}$ and transfer $5 \mathrm{ml}$ of the mixture in a "determination" tube.

Add to each of the latter tubes $0.1 \mathrm{ml}$ ferric-ammonium sulfate solution and mix.

After $10 \mathrm{~min}$ - but within 2 hours - the absorbance of the "blanks" and "determinations" are read at $623 \mathrm{~nm}$. Subtract the absorbance of the blank from the absorbance of the determination. Construct the standard curve. Read the xanthurenic acid value of the sample from the standard curve, and correct this figure for the volume of the 24-hour urine.

The absorbance of the highest standard $(400 \mu \mathrm{mol} / \mathrm{l})$ showed little variation in a 6 -month period. On 61 consecutive runs we found a mean absorbance of 0.443 with a standard deviation of 0.0185 ; coefficient of variance of 0.042 . On 31 duplicate measurements of standards and unknowns on different days we found a standard deviation of duplicates of $1.7 \mu \mathrm{mol} / 1$ xanthurenic acid.

Creatinine was determined with a kinetic Jaffé method on a Centrifugem ${ }^{\circledR} 400$ centrifugal analyzer.

The 17-hydroxysteroids were determined for the first test of group A in 24-hour urine, by a column chromatographic method (Ketochrome Bio-Rad ${ }^{\circledR}$ ).

\section{Results}

Group A and Group B consisted of 11 persons each. There is no significant difference between the groups in age (t-test), in sex (Fischer-test) (tab. 1), body height and body weight (t-test, tab. 2) or in depression and anxiety scores (t-test, tab. 3). The depression and anxiety scores are normal. The possible correlation was computed between the xanthurenic acid excretion in the 24-hour urine (range: $37-225 \mu \mathrm{mol} / 24 \mathrm{~h}$ ), and age (19-46 years), sex, height $(153-195 \mathrm{~cm})$, body weight (52-93 kg), 17-hydroxysteroid excretion (17-55 $\mu \mathrm{mol} /$ $24 \mathrm{~h})$, creatinine output $(8.8-19.5 \mathrm{nmol} / 24 \mathrm{~h}), \mathrm{pH}$ (5.5-7), Zung depression score (20-32). Hamilton depression score (0-4) and Zung anxiety score (20-30). The results of both groups together were considered for the first and for the second test separately. In both tests there was a significant correlation between the xanthurenic acid excretion and urine volume (Test $1: r=0.455$, 
Tab. 1. Age and sex of the healthy volunteers.

There is no significant difference in age (t-test) or sex (Fischer test) between the 2 groups.

\begin{tabular}{|c|c|c|c|}
\hline Group & $\begin{array}{l}\text { Age (years) } \\
\bar{x} \pm \text { S.D. }\end{array}$ & $\mathrm{N}$ & Sex \\
\hline $\begin{array}{l}\text { A } \\
\text { B }\end{array}$ & $\begin{array}{lr}27.9 & 7.8 \\
32.8 & 10.7 \\
t=1.22 \\
\text { n.s. }\end{array}$ & $\begin{array}{l}11 \\
11\end{array}$ & $\begin{array}{l}39 \quad 80 \\
6950 \\
\text { Fischer test } \\
\text { n.s. }\end{array}$ \\
\hline
\end{tabular}

Tab. 2. Height and body-weight of the volunteers.

There is no significant difference in height or body-weight of the volunteers between the 2 groups (t-test).

\begin{tabular}{|c|c|c|c|}
\hline Group & $\mathrm{N}$ & $\begin{array}{l}\text { Height } \\
(\mathrm{cm}) \\
\bar{x} \pm S . D .\end{array}$ & $\begin{array}{l}\text { Body-weight } \\
\text { (kg) } \\
\bar{x} \pm \text { S.D. }\end{array}$ \\
\hline $\begin{array}{l}\text { A } \\
\text { B }\end{array}$ & $\begin{array}{l}11 \\
11\end{array}$ & $\begin{array}{rr}175.7 & 8.7 \\
174.0 & 12.9\end{array}$ & $\begin{array}{ll}69.6 & 12.2 \\
69.2 & 12.7\end{array}$ \\
\hline t-test & & n.s. & n.s. \\
\hline
\end{tabular}

Tab. 3. Depression and anxiety scores of the volunteers.

There is no significant difference in depression or anxiety scores of the volunteers between the 2 groups ( $t$-test).

The scores are completely normal.

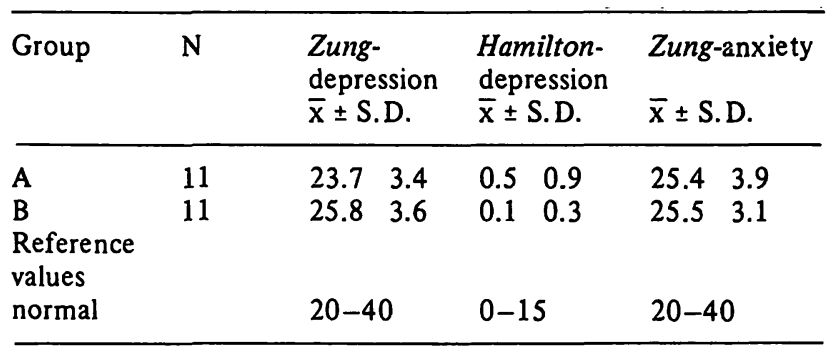

Tab. 4. Xanthurenic acid excretion in urine after different times of oral intake of $L$-tryptophan (Group A).

There is a significant difference in the variances of the xanthurenic acid excretion for the different starting-times of the experiment ( $p<0.01$ by $\mathrm{F}$-ratio test). The 2 tests are not correlated. The coefficient of variance is lower after the 22.00 hours start $(0.33)$ than after the 08.00 hours start $(0.64)$. Therefore one should start the test in the evening.

\begin{tabular}{lll}
\hline $\begin{array}{l}\text { Urine collection } \\
\text { (time interval) }\end{array}$ & $\begin{array}{l}\text { Xanthurenic acid excretion } \\
(\mu \mathrm{mol} / 24 \mathrm{~h})\end{array}$ \\
\hline $\mathrm{X} \pm \mathrm{S} . \mathrm{D}$. & \\
\hline $\begin{array}{l}08.00-08.00 \\
\mathrm{~N}=11\end{array}$ & 92.8 & 59.2 \\
$22.00-22.00$ & 56.8 & 19.0 \\
$\mathrm{~N}=11$ & $\begin{array}{l}\text { F-ratio test } \\
\text { of the variances } \\
\mathrm{p}=\end{array}$ & $\begin{array}{l}\text { F-ratio }=9.71 \\
\quad\end{array}$ \\
\hline
\end{tabular}

$p=0.04$; Test $2: r=0.461, p=0.04)$. The xanthurenic acid excretion in the first and second tests did not correlate significantly for both groups together $(\mathrm{r}=0.042)$. In Group $\mathrm{A}(\mathrm{tab} .4)$ the xanthurenic acid excretion after the 08.00 hours start is not significantly different from that after the 22.00 hours start, but the test started in the evening had a significantly lower coefficient of variance $(0.33)$ than the test started in the morning $(0.64)$ by the F-ratio test $(\mathrm{p}<0.01)$.

In Group B (tab. 5) there is no correlation between the 2 tests, both started at $22.00 \mathrm{~h}$, nor do the results of these 2 tests differ significantly in the t-test. From the participants of both groups, 31 measurements were obtained of tests from 22.00 to 08.00 hours and from 08.00 to $22: 00$ hours (tab. 6). Because the results of the first and second tests were not correlated, these 31 results can be considered toge ther.

The coefficient of variance of the summated results $(0.25)$ is clearly lower than the coefficient of variance of the $22.00-08.00$ hours $(0.47)$ or $08.00-22.00$ hours results (0.42). Thus, the summated measurements should be utilized for proper reference values, $68.8 \pm 19.0 \mu \mathrm{mol} /$ $24 \mathrm{~h}$, with a $95 \%$ confidence range of $30.8-106.8 \mu \mathrm{mol} /$ $24 \mathrm{~h}(\mathrm{n}=31)$. From these 24 -hour results the regression equation for the correlation between urinè volume $(\mathrm{ml})$

Tab. 5. Intraindividual variability of the xanthurenic acid excretion (Group B).

There is no significant difference between the results of the 2 tests, performed within one week of each other; the 2 results do not correlate $(r=0.09)$. There is a little intraindividual consistency between the tests, but there is good similarity between the 2 groups.

\begin{tabular}{llc}
$\begin{array}{l}\text { Urine collection } \\
22.00-22.00 \text { hours }\end{array}$ & $\begin{array}{l}\text { Xanthurenic acid excretion } \\
(\mu \text { mol/24h })\end{array}$ \\
\hline $\begin{array}{l}\text { First time } \\
N=11\end{array}$ & 70.2 & 21.5 \\
$\begin{array}{l}\text { Second time } \\
N=11\end{array}$ & 74.2 & 19.5 \\
t-test & $t=0.46$ & \\
& n.s. \\
\hline
\end{tabular}

Tab. 6. Xanthurenic acid excretion in urine during sequential periods after $L$-try ptophah loading (measuiements $\mathrm{n}=31$ ). The results of the tests from $22.00-08.00$ hours, from $08.00-22.00$ hours and from the total $22.00-22.00$ hours are not correlated. The first test of all for every participant was started at 22.00 hours. Therefore all second measurements at the 22.00 hours start could be taken into account for computations $(n=31)$. The summated results show a lower coefficient of variance $(0.25)$ than either the $22.00-08.00$ houirs portion $(0.47)$ or the subsequent $08.00-22.00$ hours portion $(0.42)$. Thus, one should collect the urine for 24 hours, and $68.8 \pm 19.0 \mu \mathrm{mol} / \mathrm{h}$ are the new reference values.

\begin{tabular}{|c|c|c|c|}
\hline \multirow{2}{*}{$\begin{array}{l}\begin{array}{l}\text { Collection period } \\
\text { (time interval) }\end{array} \\
\begin{array}{l}22.00-08.00 \\
n=31\end{array}\end{array}$} & \multicolumn{3}{|c|}{$\begin{array}{l}\text { Xanthurenic acid excretion } \\
(\mu \mathrm{mol} / \text { time period }) \\
\overline{\mathrm{X}} \pm \text { S.D. }\end{array}$} \\
\hline & 37.0 & 17.4 & \\
\hline $\begin{array}{l}08.00-22.00 \\
n=31\end{array}$ & 31.7 & 13.8 & $\cdot$ \\
\hline $\begin{array}{l}\text { Total: } \\
22.00-22.00 \\
n=31\end{array}$ & 68.8 & 19.0 & \\
\hline
\end{tabular}


and xanthurenic acid excretion ( $\mu \mathrm{mol} / 24 \mathrm{~h})$ was computed:

Xanthurenic acid $=0.022 \times(\mathrm{vol} .(\mathrm{ml})+37.23)$.

The correlation for the 31 values is rather high $(r=0.578)$.

\section{Discussion}

The colorimetric method is reliable and gives reproducible results. Although the standard curve is not linear for low xanthurenic acid values, the sensitivity of the test is sufficient with an S.D. of $1.7 \mu \mathrm{mol} / \mathrm{l}$. One technician can perform manually 10 xanthurenic acid determinations in about 2 hours.

The coefficient of variance of the xanthurenic acid excretion after a morning test-start is significantly higher than that after the evening start. It is therefore questionable whether one should in fact start these tests in the morning, as described in the literature $(3,4,6)$. The greater variability in xanthurenic acid excretion after the morning start is not correlated with the output of 17-hydroxysteroids over 24 hours. It is however quite possible, that the plasma concentrations of cortisol in the morning are relevant. This should be further investigated. Since the results of the morning and evening tests (tab. 4) do not differ significantly, but the coefficient of variance of the two tests do differ significantly, the xanthurenic acid excretion is a sensitive physiological parameter, and the test should be started in the evening. The results of the first and second tests demonstrate that prior loading with $L$-tryptophan does not influence the results of a second test within one week. Since the results of the evening tests (tab. 5) are highly reproducible for the group participants, the xanthurenic acid excretion is a reliable physiological parameter. Because the correlation between the $22.00-08.00$ hours and $08.00-22.00$ hours portions is very low $(r=0.04)$, and the summated results have a clearly lower coefficient of variance than the results of the 2 portions, the urine should be collected during 24 hours (tab. 6).

It is possible that the $L$-tryptophan dose is important for the urine collection period. Authors using shorter urine collection periods administered lower $L$-tryptophan doses: $2.0-3.5 \mathrm{~g}(4,6,12)$; one of them (12) found that a collection period of 6 hours is enough if $2 \mathrm{~g}$ of $L$-tryptophan are administered. But the low correlation points to great interindividual differences in the excretion-time curve.

The correlation between xanthurenic acid excretion and urine volume is probably restricted to heal thy volunteers. Thus, in a previous study of the xanthurenic acid excretion in 139 psychiatric patients, no correlation between urine volume and xanthurenic acid excretion was found. The variances of the xanthurenic acid excretion by the psychiatric reference group of that study $(101.5 \pm 65.1 \mu \mathrm{mol} / 24 \mathrm{~h}, \mathrm{~N}=26)$, differ significantly from that of the $68.8 \pm 19.0$ reference values found in this study (F-ratio 11.74; $p=0.001)(7)$. This means that the influence of urine volume on xanthurenic acid excretion is easily overruled by other factors. The correlation should however be checked in future studies.

The 5 gram dose of $L$-tryptophan gives satisfactory values for the xanthurenic acid excretion if the test is started in the evening (coefficient of variance $=0.25$ ). From the literature, it is not clear what the effect of a lower $L$-tryptophan dose would be. These comparisons are hampered by the differences in test procedures. The 5 gram dose in the evening is certainly not distressing to volunteers or patients. Only 3 volunteers in this study had complaints, notably of sleepiness for some hours in the morning tests.

The present reference values are approximately normally distributed $(n=31)$. The old reference values were positively skewed with a modus of $50 \mu \mathrm{mol} / 24 \mathrm{~h}$ $(\mathrm{N}=648)$. Of these 648 values just 327 values are found within the $95 \%$ confidence range $(30.8-106.8 \mu \mathrm{mol} /$ $24 \mathrm{~h}$ ) of the new reference values. The approximate normal distribution of the new reference values strengthtens the probability that xanthurenic acid excretions of 0-30.8 $\mu \mathrm{mol} / 24 \mathrm{~h}$ should be considered abnormal. At the biochemical level this can be understood, because the enzyme metabolizing 3-hydroxykynurenine to xanthurenic acid contains pyridoxal phosphate (vitamin $\mathrm{B}_{6}^{*}$ ) as co-factor (fig. 1) (17). Since this enzyme is less sensitive to a vitamin $B_{6}$ deficiency or competitive inhibition of vitamin $B_{6}^{*}$ containing enzymes, the xanthurenic acid excretion will first rise during these disorders of the nicotinamide synthesis $(2,4)$. Eventually, the vitamin $\mathrm{B}_{6}^{*}$ deficiency or the competitive inhibition can prevent further synthesis of xanthurenic acid. The xanthurenic acid excretion then drops to zero. If this hypothesis is correct, it means that the $0-30.8 \mu \mathrm{mol} / 24 \mathrm{~h}$ values are the most pathological, and not the very high values, for example 2000-3000 $\mu \mathrm{mol} / 24 \mathrm{~h}$. By measurement of the xanthurenic acid excretion alone, it is not possible, however, to discriminate between the relative contribution of an induction of pyrrolase or disorders in the vitamin $\mathrm{B}_{6}^{*}$ containing enzymes (18).

In conclusion, the xanthurenic acid is measured by the colorimetric method in a sensitive, reproducible and easy manner. The xanthurenic acid excretion reflects, in a sensitive and reproducible manner, the physiological state of the nicotinamide biosynthesis. The 5 gram $L$-tryptophan dose should be administered in the evening, the urine should be collected over 24 hours and, at least in volunteers, the urine volume should be considered as an independent variable of the xanthurenic acid excretion.

\section{Acknowledgement}

The authors are grateful to the staff of the departments of Clinical Chemistry, Physical Therapy and Clinical Neurophysiology, of the Bethesda Hospital, Tiel, who volunteered for the tests. The statistical analysis was performed by $N$. Sijben, research psychologist. 


\section{References}

1. Wachstein, M. \& Gudaitis, A. (1952), Am. J. Clin. Pathol. 22, 10. Weller, H. \& Fichtenbaum, M. (1961), Klin. Wochenschr. 652-655.

2. Green, A. R. (1978), in "Essays in Neurochemistry, vol. III", p. 103-129 (Youdim, M. B. H., Lovenberg, W., Sharman, D. F. \& Lagnado, J. R., eds.) Wiley, New-York.

3. Adams, P. W., Rose, D. P., Folkard, J., Wynn, V., Seed, M. \& Strong, R. (1973), Lancet I, 897-904.

4. Coelingh Bennink, H. J. T. \& Schreurs, W. H. P. (1974), Contraception 9, 347-356.

5. Schmitz, K. W., Grimm, U., Schulz, M., Smetan, M., Knapp, A. \& Schmitz, W. (1974), Psychiat. Neurol. Med. Psychol. $26,353-357$.

6. Sabater, J. \& Ricos, C. (1974), Clin. Chim. Acta 56, $175-$ 186.

7. Hoes, M. J. A. J. M. (1979), Acta Psychiat. Belg. 79, 638646.

8. Hoes, M. J. A. J. M. (1979), Tijdschr. Psychiat. 21, 302-321.

9. Hoes, M. J. A. J. M., Colla, P. \& Folgering, H. (1981), J. Orthomol. Psychiat. 10,7-15.

39, 1275-1280.

11. Kochen, W., Byrd, D. J., Bühner, R. \& Bührlen, E. (1975), Z. Klin. Chem. Klin. Biochem. 13,1-12.

12. Cazzullo, G. L., Magnoni, A. \& Mascherpa, G. (1966), Brit. J. Psychiat. 112, 157-162.

13. Hardeland, R. (1977), in "Proceedings of the XII international conference on the International Society for Chronobiology" p. 583-589 (Halberg, F. ed.) Il Ponte, Milano.

14. Hamilton, M. (1967), Brit. J.. Soc. Clin. Psychol. 6, 278296.

15. Zung, W. W. K. (1965), Arch. Gen. Psychiat. 12, 63-70.

16. Zung, W. W. K. (1971), Psychosomatics 12, 371-379.

17. Schulz, M., Grimm, U., Schmitz, W. \& Knapp, A. (1973), Psychiat. Neurol. Med. Psychol. 25, 98-106.

18. Wolf, H., Brown, R. R. \& Arend, R. A. (1980), Scand. J. Clin. Lab. Invest. 40, 9-14.

M. J. A. J. M: Hoes, M. D. Lecturer for Biological Psychiatry Department of Psychiatry, Radboud Hospital University of Nijmegen Theodoor Craanenlaan 4 NL-6500 HB Nijmegen 